\title{
DA LEITURA NA ESCOLA PARA A LEITURA DO MUNDO: ROTEIROS DE LEITURA COMO PROPOSTA PEDAGÓGICA ${ }^{1}$
}

\author{
Juracy Assmann Saraiva (FEEVALE) \\ Tatiane Kaspari (FEEVALE) \\ Márcia Rohr Welter (UNISINOS)
}

Resumo: O reconhecimento da função formadora da literatura respalda sua defesa enquanto direito humano (CANDIDO, 2011). Tendo em vista as restrições a esse direito dentre grande parcela da população, a escola torna-se, por excelência, centro de difusão cultural, que deve fomentar o desenvolvimento de leitores críticos e competentes, capazes de estender seu protagonismo na interpretação de textos à participação social. Esse propósito motiva a realização do presente trabalho, que visa discutir reflexos da abordagem escolar do texto literário na (de) formação de leitores no Ensino Médio e a indicar, como possibilidade pedagógica, os roteiros de leitura, propostos por Juracy Assmann Saraiva et al (2001, 2006, 2011, 2015). Parte-se do pressuposto, expresso por pensadores como Ligia Cademartori (2012), Marisa Lajolo (2001, 2002), Teresa Colomer (2007) e Vincent Jouve (2012), de que é necessário oferecer aos alunos uma variedade de textos com potencial simbólico, cuja leitura esteja inscrita em um processo de análise e de reflexão textual, capaz de deflagrar o exercício interpretativo em que dialogam horizontes de expectativa do leitor e da obra (JAUSS, 1978). Nessa perspectiva, os roteiros de leitura orientam a trajetória do aluno em sua interação textual, conforme exemplificado por resultados da aplicação do roteiro sobre Harry Potter e a pedra filosofal em duas turmas de Ensino Médio. A experiência possibilitou a alunos posicionarse a respeito da qualidade da narrativa e comparar seus elementos com outras obras lidas. Além disso, os estudantes problematizaram o conceito escolar de literatura e assumiram sua voz no debate cultural provocado pela leitura.

Palavras-chave: Literatura; Leitor; Ensino Médio; Roteiros de leitura.

1 Título em espanhol: "De la lectura en la escuela para la lectura del mundo: guiones de lectura como propuesta pedagógica". 
Resumen: El reconocimiento de la función formadora de la literatura respalda su defensa como derecho humano (CANDIDO, 2011). Teniendo en cuenta las restricciones a este derecho entre gran parte de la población, la escuela se convierte por excelencia en un centro de difusión cultural, que debe fomentar el desarrollo de lectores críticos y competentes, capaces de extender su protagonismo en la interpretación de textos a la participación social. Este propósito motiva la realización del presente trabajo, que trata de discutir reflejos del abordaje escolar del texto literario en la (de)formación de lectores en la Enseñanza Media e indicar, como posibilidad pedagógica, los itinerarios de lectura, propuestos por Juracy Assmann Saraiva et al (2001, 2006, 2011, 2015). Se parte del presupuesto, expresado por pensadores como Ligia Cademartori (2012), Marisa Lajolo (2001, 2002), Teresa Colomer (2007) y Vincent Jouve (2012), que es necesario ofrecer a los alumnos una variedad de textos con potencial simbólico, cuya lectura esté inscrita en un proceso de análisis y de reflexión textual, capaz de desencadenar el ejercicio interpretativo en que dialogan horizontes de expectativa del lector y de la obra (JAUSS, 1978). En esta perspectiva, los guiones de lectura orientan la trayectoria del alumno en su interacción textual, según lo ilustrado por resultados de la aplicación del guión sobre Harry Potter y la piedra filosofal en dos clases de Enseñanza Media. La experiencia posibilitó a los alumnos posicionarse sobre la calidad de la narrativa y comparar sus elementos con otras obras leídas. Además, los estudiantes problematizaron el concepto escolar de literatura y asumieron su voz en el debate cultural provocado por la lectura.

Palabras clave: Literatura; Lector; Enseñanza Media; Rutas de lectura.

\section{QUANDO (E COMO) LÊ O ALUNO DE ENSINO MÉDIO?}

O analfabetismo é uma ferida aberta na democracia brasileira, visto que impõe restrições significativas de participação social a $8 \%$ da população acima de 15 anos, segundo dados divulgados em 2016 pelo Instituto Brasileiro de Geografia e Estatística (IBGE). Quando ampliada a noção de analfabetismo, de modo a abarcar os indivíduos 
cuja proficiência em leitura não ultrapassa o nível de decodificação do código escrito, chega-se a $27 \%$ dos brasileiros na condição de analfabetismo funcional, segundo informações do Indicador de Alfabetismo Funcional (INAF), pesquisa realizada pelo Instituto Paulo Montenegro, em parceria com a ONG Ação Educativa e o Instituto Brasileiro de Opinião Pública e Estatística (IBOPE Inteligência).

Essa situação tem motivado esforços de sucessivos governos, como o atual de Michel Temer, para quem a alfabetização é "uma política de educação prioritária" (MEC, 2016, on-line). Assim, concentram-se investimentos em programas como Brasil Alfabetizado e na ampliação do Programa Nacional do Livro Didático (PNLD), que, a partir de 2017, prevê a aquisição de livros consumíveis até o 5o ano. Paradoxalmente, porém, o Programa Nacional da Biblioteca da Escola (PNBE), que prevê a distribuição de acervos de obras literárias a escolas públicas, sofreu, na edição de 2015, um adiamento que resultou em sua silenciosa suspensão em 2017. A justificativa, dada pela equipe do então ministro Renato Janine Ribeiro, para o abandono a essa iniciativa seria que, em tempos de cortes orçamentários, "as obras de literatura são consideradas menos prioritárias" (RAMOS, 2015, on-line). 
Tal posicionamento fere os princípios de uma formação leitora plena e emancipadora, visto que o analfabetismo funcional atinge indivíduos de todos os setores sociais e com os diferentes níveis de ensino. No Ensino Médio, estima-se que $11 \%$ dos alunos não saibam compreender informações explícitas em paralelo com apenas 9\% de leitores proficientes, segundo o INAF. Tais dados ajudam a compreender, por exemplo, o motivo pelo qual a área de Linguagens apresentou, na edição do Exame Nacional do Ensino Médio (ENEM) de 2016, a média mais baixa por área, 287,5, e por que o número de redações com nota máxima nessa prova tem decaído - em 2014, foram 250 textos considerados excelentes contra 104, em 2015, e apenas 77 em 2016.

Nesse contexto, a leitura e o estudo de obras literárias desponta como meio privilegiado de desenvolvimento da capacidade leitora em contexto escolar, visto que alia o conhecimento de recursos linguísticos em interação na unidade textual à possibilidade de identificação do leitor e, consequentemente, de sua formação emocional, identitária, moral. Alinhado a essa perspectiva, inscrita em estudos como de Ligia Cademartori (2012), Marisa Lajolo (2001, 2002), Teresa Colomer (2007) e Vincent Jouve (2012), o presente artigo apresenta como proposta pedagógica para 
o ensino de literatura os roteiros de leitura. Essa abordagem metodológica, formulada por Juracy Assmann Saraiva et al (2001, 2006, 2011, 2015), tem por base reflexões da Estética da Recepção e busca situar o aluno-leitor como protagonista do processo de interpretação textual.

Com vistas a exemplificar a aplicabilidade da proposta, enquanto deflagradora do diálogo cultural na escola, são apresentados resultados da aplicação de um roteiro de leitura acerca de Harry Potter e a pedra filosofal em duas turmas de 10 ano de Ensino Médio. Por um lado, as dificuldades enfrentadas pelos estudantes na realização das atividades demonstram carências significativas na formação leitora, sobretudo no que diz respeito à capacidade de abstração e de correlação de ideias. Por outro lado, há que se sublinhar o desejo desses jovens em participar de debates acerca da leitura de obras literárias e de suas relações com a realidade. Dessa forma, o roteiro de leitura extrapola a mera análise da obra em foco, estimulando o desenvolvimento do senso crítico e deflagrando reflexões relevantes acerca do papel que compete à literatura na formação dos indivíduos.

\section{POR QUE LER NA ESCOLA?}

A leitura de obras literárias deslumbra o ser humano, seja pelo jogo de possibilidades instaurado pela linguagem, seja 
pelos diversos mundos fictícios capazes de transportar o leitor a universos diversos e semelhantes ao seu contexto histórico e social. O fato é que a literatura possibilita criar diferentes significações que somente o leitor pode efetivar.

A despeito do papel do receptor na construção de sentido, até certo ponto da história, os estudos literários concentraram-se na decodificação do texto, tido como mero instrumento de análises estruturalistas. Essas análises, que renegavam o papel do leitor, davam ênfase aos aspectos físicos do texto, como os signos e o gênero, e a dados extratextuais, como o contexto histórico da publicação da obra e a biografia do autor, cuja vida, interesses e/ou obsessões apareciam inscritos em sua criação. Com o passar dos anos, essa concepção estanque dos estudos de literatura foi se esgotando e, na década de 1970, começaram a surgir novas possibilidades de reflexões sobre a recepção textual.

Uma nova perspectiva se desenhou a partir da Escola de Constância, cujos pressupostos teóricos bifurcam-se basicamente em duas vertentes: a Estética da Recepção, defendida por Hans Robert Jauss, e a Teoria do Efeito Estético, elaborada por Wolfang Iser. Na direção da valorização do leitor, no final da década de 1970, a análise semiótica foi redimensionada com os trabalhos de Umberto Eco, que reflete 
sobre as maneiras como um texto programa a sua recepção, criando, assim, um leitor-modelo. Na sequência, os estudos de Philippe Hamon e M. Otten sugerem enfocar as características do ato de leitura. E, por último, em meados da década de 1980, Michel Picard procura lançar um olhar psicanalítico sobre o leitor real de uma obra, que é dotado de anseios, saberes e convenções sócio-históricas (JOUVE, 2002).

Os estudos da recepção, que colocam o leitor como protagonista do ato interpretativo, podem ser, de forma generalizada, e salvaguardando algumas diferenças, divididos em duas abordagens: uma que considera a leitura "em suas consequências globais na sociedade" e outra que enfoca o "efeito particular que produz no indivíduo" (JOUVE, 2002, p.125). Para Jauss, a análise de sentido do texto deve considerar os dois pontos que a integram, o efeito produzido pela obra e a sua recepção (JAUSS, 1978).

Nessa perspectiva, a leitura não é um processo estanque, mas uma ação na qual o leitor investe "as expectativas concretas que correspondem ao horizonte de seus interesses, desejos, necessidades e experiências tais quais são determinadas pela sociedade e classe à qual pertence como também pela sua história individual" (JAUSS, 1978, p.259). Assim, a leitura nunca está restrita apenas ao mundo fantástico que institui, mas também aos sentidos a ela atribuídos pelo leitor. 
Jauss também elabora a concepção cultural de leitura, na qual os olhares direcionados às obras variam de acordo com as épocas e com os leitores. Por conseguinte, uma obra, em seu lançamento, pode condizer com os valores sociais de seus leitores, mas, posteriormente, suscitar questionamentos que não eram possíveis na sua publicação, ou pode deflagrar o caminho inverso. Nessa acepção, a literatura tem o potencial de (de)formação de mentalidades, uma vez que a multiplicidade de interpretações é comum aos textos literários em decorrência da plurissignificação da linguagem. Sendo assim, o texto permite, em sua leitura

[...] vários pontos de entrada e vários pontos de fuga. Os pontos de entrada corresponderiam a múltiplas posições do sujeito. Os pontos de fuga são as diferentes perspectivas de atribuição de sentidos: ao relacionar-se com os vários pontos de entrada, o leitor pode produzir leituras que encaminham-se em várias direções. Não necessariamente previstas, nem organizadas, nem passíveis de cálculo. Há várias perspectivas de leituras. [...] Os pontos de entrada são efeitos da relação do sujeito-leitor com a historicidade do texto. Os pontos de fuga são o percurso da historicidade do leitor, em relação ao texto. (ORLANDI, 1988, p.59)

Entretanto, as singularidades interpretativas não permitem qualquer interpretação, pois cada texto prevê um leitor-modelo, 
que não equivale ao destinatário real, mas a "um conjunto de condições de êxito, textualmente estabelecidas, que devem ser satisfeitas para que um texto seja plenamente atualizado no seu conteúdo potencial" (ECO, 1986, p.45). O receptor também não pode fazer uso indiscriminado do texto, mas lhe é permitido uma variedade de interpretações a partir do que é posto pelo texto.

Sob a percepção de que a leitura exige o protagonismo do leitor, a escola deve se fazer espaço privilegiado para o acesso à literatura. No processo, repleto de percalços, de transformar alunos em leitores, as instituições não podem abdicar das dimensões lúdica, libertadora e crítica da leitura, pois ao ler, o sujeito vê-se como ser intelectual, político, histórico, cultural e socialmente engajado.

Sendo assim, a literatura deve ocupar papel fundamental na formação do indivíduo, porque o texto literário é, ao mesmo tempo, subjetivo/individual e social/coletivo. Como estão ligados a contextos sócio-históricos, os textos literários permitem discussões nas esferas dos sentimentos humanos e, pela construção peculiar, que foge ao sentido literal dos signos, abrem espaço para que o leitor se sinta como participante do processo de produção de sentidos. Eles dispensam a adequação à realidade, mas não abandonam o real, pois o leitor é um ser histórico e social. Nessa relação, o 
receptor encontra imagens deformadoras, que não condizem com a sua existência, e imagens informadoras, que dizem respeito a si próprio e que permitem olhar para o seu interior, reconhecendo o outro e observando a si mesmo (SARAIVA, MÜGGE, 2006). É por auxiliar o leitor a reordenar seu caos interior, por gerar solidariedade e energia que liberta da tensão cotidiana e por resistir contra a homogeneização cultural, que o texto literário interfere na vida dos indivíduos.

Conforme Candido (2002, p.77-92), a literatura possui a função de humanizar o indivíduo, pois, por meio dela, o leitor compartilha, de modo subjetivo, da ficção e de sua condição social. O teórico também afirma que a criação artística pode atuar na formação da criança e do adolescente tanto quanto a escola e a família, visto que a arte "age com o impacto indiscriminado da vida e educa como ela - com altos e baixos, luzes e sombras" (CANDIDO, 2002, p.83).

Sendo assim, é importante que o estudo da literatura ocupe um papel protagonista nas instituições de ensino, porque ela toca o humano, atinge a sensibilidade dos indivíduos, provocando inquietações ou reafirmando ideais. Para que, de fato, a literatura cumpra seu papel de inquietação e desacomodação, torna-se indispensável que as escolas sejam um espaço que promova a leitura de forma sistemática, crítica e reflexiva. 


\section{COMO LER NA ESCOLA?}

No contexto atual, a literatura está inserida na escola por meio da proposição da disciplina no currículo do Ensino Médio, a partir dos Parâmetros Curriculares Nacionais (PCNs) de 2006 ². Sua presença no programa de atividades não equivale, contudo, a uma valorização efetiva, conforme revela uma pesquisa ${ }^{3}$, realizada pelo Centro Brasileiro de Análise e Planejamento (CEBRAP) e pela Fundação Victor Civita (FCV). Ao entrevistar mil jovens paulistanos e recifenses, os estudantes ou evadidos do Ensino Médio avaliaram a disciplina de Literatura como a que possui a menor relevância para a vida profissional.

Nessa percepção, a literatura é considerada inútil para a maioria dos jovens, porque não apresenta ensinamentos que sejam úteis para o mercado de trabalho. Contudo, um dos principais papéis da literatura é justamente promover uma inclusão sociocultural, permitir que jovens almejem condições de vida melhores e que possam atuar ativamente na sociedade.

2 As orientações curriculares de 2006 retificam parcialmente os PCNs de 2002 (em que o ensino da Literatura era incorporado ao de Língua Portuguesa), considerando que estes "passaram ao largo dos debates que o ensino de tal disciplina vem suscitando, além de negar a ela a autonomia e a especificidade que Ihe são devidas" (BRASIL, 2006, p.49). Desde 2015, porém, tramita a proposta de uma Base Nacional Comum Curricular (BNC), em que a Literatura é novamente inserida como componente da disciplina de Língua Portuguesa (mais informações podem ser acessadas em: http://basenacionalcomum.mec.gov.br/. Acesso em: 19.Abr.2017).

3 Os dados da pesquisa constam, na íntegra, do relatório disponível em: http://www.fvc. org.br/estudos-e-pesquisas/2012/pdf/relatorio_jovens_pensam_escola.pdf Acesso em: 01.Abr.2017. 
Para que a escola cumpra seu papel de fazer com que "[...] as novas gerações incursionem no campo do debate permanente sobre a cultura" (COLOMER, 2007, p.29), é preciso que seja realizado um trabalho que permita ao aluno interessar-se pela leitura de obras literárias. Para romper com "uma tradição escolar pobre e improvisada" (LAJOLO, 2002, p.21), o primeiro passo é disponibilizar ao professor uma formação continuada, de modo que seja capacitado a intervir no ensino de literatura baseado em fragmentos e em "características" do movimento literário estudado e a posicionar-se frente à situação mercadológica do universo literário na atualidade.

Um segundo momento desse processo é envolver os alunos em um trabalho contínuo com a leitura, em que ela seja inserida em projetos prolongados e de caráter interdisciplinar. Nesse planejamento, é interessante abarcar obras contemporâneas voltadas ao público infanto-juvenil, pois a fruição também exige esforço intelectual, bem como obras do cânone literário, porque a formação do leitor literário exige o desenvolvimento da consciência crítica. Pensando nisso, a relação texto leitor, na qual o texto é objeto significante e o leitor constrói o seu significado, "[...] depende, no âmbito do ensino básico, da seleção adequada das obras ao desenvolvimento afetivo e 
cognitivo dos alunos e do tratamento dispensado pelo professor à sua exploração" (SARAIVA, 2006, p.46).

A construção de sentido do texto literário e da leitura deve ser processual, pois

[...] por um lado, a estrutura lacunar do texto exige a participação do leitor; por outro, a leitura a que ele procede é influenciada por seu comportamento linguístico e por suas condições socioculturais. Em decorrência disso, as significações do texto adquirem um caráter mutável e transitório, visto que se expandem em função da atividade do leitor; e ele, por sua vez, sofre os efeitos da leitura, pois esse ato cognitivo é não apenas influenciado por sua experiência de mundo, como também a modifica, uma vez que passa a fazer parte dela. (SARAIVA, 2006, p.48)

Sendo assim, "o enfoque na relação texto-leitor ressalta a compreensão de que o texto literário é um espaço no qual se desenham hipóteses significativas que, seguidas pelo leitor, permitem-Ihe atribuir sentidos ao seu próprio mundo" (SARAIVA, 2006, p.48). Para que se possa perseguir essas significações e atribuir sentidos ao próprio mundo, é necessário “[...] levar o leitor a perder a inocência que deve perder e a enxergar o que temia ver" (CADEMARTORI, 2012, p.62), com um trabalho de literatura continuado que abarque as possibilidades interpretativas do texto. 
Com esse objetivo, apresenta-se como proposta o trabalho com roteiros de leitura, cuja metodologia, proposta por Juracy Assmann Saraiva et al (2001, 2006, 2011, 2015), organiza-se em três etapas - entender, interpretar e aplicar -, que são apoiadas no caráter estético do texto. Ao final do processo de compreensão e intepretação, o leitor poderá responder às seguintes interrogações: "O que o texto diz?"; "Como o texto diz o que diz?"; "Qual é o sentido do texto?"; "Que diálogo há entre o texto e o contexto estético-históricocultural atual e o do momento de sua produção?".

No primeiro momento, é proposta uma atividade introdutória de recepção ao texto. Nessa etapa, realizada antes da leitura da obra, o professor visa instigar os alunos à leitura, suscitando questionamentos ou problematizando tópicos que, de algum modo, estão relacionados à obra selecionada. A partir do trabalho de motivação, o professor estabelece um prazo de leitura.

O início das atividades de interpretação e construção de sentidos, que constitui a etapa da leitura compreensiva, exige a leitura integral da obra, pois, nesse processo, são discutidas as pistas iniciais para a apreensão de especificidades da composição do texto. Constantemente, é exigido que o leitor retorne à obra para que, com as chaves fornecidas 
por ela, consiga adentrar os sentidos para a compreensão. Para isso, é preciso investigar o conteúdo, bem como a expressão do texto narrativo: identificação da estrutura das ações, caracterização das personagens, localização espaço-temporal, análise do processo de comunicação entre narrador e narratário, expressão de posições ideológicas, presença de modalidades de discurso, análise de outros textos inscritos na superfície do texto e abordagem de reflexões metaficcionais (SARAIVA, 2006).

Na sequência, ocorre a leitura interpretativa, em que se “justifica ou não a compreensão prévia ao confrontar o resultado da análise crítica dos componentes textuais à significação inicialmente atribuída ao texto" (SARAIVA, 2006, p.50). Nessa etapa, o leitor correlaciona o texto "à sua situação pessoal, de modo que a significação textual passa a impregnar-se de sentido, isto é, da experiência humana, cultural e historicamente situada, possibilitando que o texto se interponha como uma ponte entre o leitor e o mundo" (SARAIVA, 2006, p.50).

A última etapa do roteiro, Transferência e Aplicação, caracteriza-se como uma possibilidade de ampliar a experiência literária, pois o leitor é conduzido a relacionar a obra lida com outras manifestações, integrando variados campos de expressão artística ao seu conhecimento (SARAIVA, 2006). Essa 
etapa dos roteiros pode estar eventualmente relacionada a uma atividade lúdica, por exemplo, um jogo que promova, ao mesmo tempo, descontração e ampliação dos conhecimentos; e, obrigatoriamente, a uma produção - pintura, texto, curtametragem, etc. - que faça o aluno dialogar com uma temática ou com algum elemento da obra.

As atividades desenvolvidas durante as etapas explanadas são construídas de modo a serem interessantes aos alunos, ou seja, com esquemas e imagens que facilitem a compreensão e que proporcionem ao aluno caminhos para ir além da superfície textual.

Desse modo, a metodologia se mostra eficiente, pois, além de aprimorar a competência linguística e formar leitores, possibilita ao aluno colocar-se no papel de protagonista dos estudos literários. Esse movimento permite também abrir espaço para a reflexão e a construção de sujeitos capazes de intervir na sociedade, pois, a partir da sensibilização provocada pela literatura, desenvolvem habilidades emotivas, sociais e cognitivas.

\section{AINDA É POSSÍVEL FORMAR LEITORES NA ESCOLA?}

Experiências de sucesso na formação de leitores e no engajamento social dos sujeitos da educação tendem a ser ofuscadas pela ampla divulgação das deficiências do sistema 
de ensino brasileiro, contribuindo para a sensação de impotência frente à realidade e, por vezes, desestimulando ações docentes. Por esse motivo, faz-se relevante a menção a resultados positivos já alcançados com o trabalho sistemático com roteiros de leitura. Dentre as variadas iniciativas derivadas da proposta metodológica elaborada por Saraiva et al, citam-se o programa Carrossel de Letras e o projeto "Texto literário: espaço de reflexão crítica e de formação de sujeito".

Destinado a alunos da rede municipal de Dois Irmãos cidade da Serra Gaúcha, com aproximadamente 27.500 habitantes -, o Carrossel de Letras foi implantado em 2004. Suas ações contemplaram a capacitação de professores, a leitura extensiva de poemas e de narrativas, a análise sistemática dos textos literários por meio de roteiros de leitura, a produção de textos pelos alunos em diferentes linguagens e sua divulgação por meio de eventos e da mídia. O efetivo engajamento da comunidade escolar no programa e os intercâmbios com a população do município evidenciaram a leitura como prática social e granjearam o reconhecimento público, como comprova o recebimento do Prêmio Gestor Público, concedido pela Associação dos Auditores Fiscais do Rio Grande Sul. Acrescentam-se a 
esses resultados concretos do Carrossel de Letras outros, menos palpáveis, mas igualmente importantes porque são referentes à educação da sensibilidade, que harmoniza o convívio humano, integra culturas, reforça laços identitários, promove o desenvolvimento pleno do indivíduo.

Uma década após o Carrossel de Letras, durante o ano letivo de 2014, foi concretizado o projeto "Texto literário: espaço de reflexão crítica e de formação de sujeito", no âmbito do "Programa de Iniciação em Ciências, Matemática, Engenharias, Tecnologias Criativas e Letras" (PICMEL), fomentado pela Fundação de Amparo à Pesquisa do Estado do Rio Grande do Sul (FAPERGS). Conforme previsto em edital, inicialmente, participaram das atividades duas professoras e seis alunas bolsistas, às quais cabia, após encontros prévios com a docente para discussão de textos literários e de pressupostos teóricos adaptados à sua linguagem, estimular a leitura de poemas e de narrativas por seus colegas e orientar a realização das atividades previstas em roteiros de leitura. O protagonismo conferido às alunas em aula implicou em questões identitárias, repercutindo em maior engajamento das turmas de Ensino Médio nas tarefas previstas e, consequentemente, no rendimento escolar e no convívio entre os jovens. 
O PICMEL é um exemplo de programa promissor, ao fomentar o intercâmbio entre os estudos acadêmicos e o contexto escolar, que, todavia, acabou extinto precocemente. Não obstante, desde 2015, o projeto "Texto literário: espaço de reflexão crítica e de formação de sujeito" mantém-se pela participação voluntária de um grupo de professores e de interessados em literatura - que incluem bolsistas de 2014, hoje acadêmicas dos cursos de Letras, Direito e Arquitetura-, que debatem a leitura de textos literários, vinculando-os ao contexto escolar, seja pela formulação de roteiros de leitura, seja pela aplicação de projetos relacionados à literatura.

Dessa maneira, por um lado, o Carrossel de Letras evidencia que os êxitos advêm de forma mais rápida e palpável quando as atividades de leitura estão circunscritas em uma abordagem sistêmica e integrada da rede de ensino, com o respaldo da gestão pública. Por outro lado, porém, o projeto "Texto literário: espaço de reflexão crítica e de formação de sujeito" aponta para a viabilidade de mobilização dos sujeitos da educação, de forma a promover mudanças significativas na abordagem do texto literário e, por extensão, no desenvolvimento da capacidade leitora dos alunos. Ressalte-se, porém, que ambos os projetos constroem a base do trabalho com roteiros de leitura em 
sala de aula na capacitação dos professores, cuja proficiência leitora orienta os estudantes no percurso de interpretação dos textos.

Considerando-se, em particular, o Ensino Médio, tem-se um nível de ensino a cargo do poder estadual, que enfrenta graves crises financeiras em diversas unidades federativas. Por conseguinte, ações sistemáticas na área da formação leitora, de implantação imediata e com investimentos sólidos, são improváveis, requisitando de professores, equipes diretivas e comunidade em geral, iniciativas que priorizem a alfabetização em seu sentido mais amplo, a despeito da conjuntura desfavorável que se apresenta em grande parte das escolas brasileiras. A somatória de ações singulares não é a operação ideal, mas, certamente, apresenta um saldo positivo à educação.

Nessa perspectiva, discutem-se a seguir alguns resultados do trabalho desenvolvido a partir do roteiro de leitura sobre Harry Potter e a pedra filosofal, em duas turmas de 10 ano de uma escola estadual de ensino médio, localizada na cidade gaúcha de São Sebastião do Caí. A ação integra a pesquisa de doutorado de AUTOR, que visa a discutir a leitura e a abordagem pedagógica de obras literárias no contexto escolar, considerando especialmente fatores culturais e identitários envolvidos na recepção. 
A seleção da obra a ser lida derivou de uma pesquisa prévia com 328 alunos de três instituições de ensino médio públicas, aos quais foi questionado qual a melhor obra literária que já haviam lido. O texto citado com maior recorrência foi Dom Casmurro, com 30 menções, seguido de $O$ cortiço, com 15, e da saga Harry Potter, com 10. Considerando a complexidade da obra literária e a possibilidade de maior identificação, julgou-se conveniente iniciar o trabalho com a obra infantojuvenil contemporânea, para, no próximo ciclo letivo, proceder à leitura de clássicos.

\section{ALUNOS BRASILEIROS LEEM HARRY POTTER NA ESCOLA?}

O contexto escolar da instituição em que se inserem os alunos a quem foi recomendada a leitura de Harry Potter e a pedra filosofal desenha-se favorável à prática da leitura. Embora não haja bibliotecário, a equipe diretiva organizou uma escala de horários para que a biblioteca ficasse aberta aos alunos, que têm à sua disposição títulos variados, catalogados e dispostos em prateleiras organizadas. Com a contribuição da comunidade, há uma constante renovação do acervo, especialmente com a aquisição de obras contemporâneas e destinadas ao público infantojuvenil, o que repercute na avaliação positiva da biblioteca por $85 \%$ dos alunos entrevistados nessa escola. Nessa conjuntura 
de incentivo à leitura, soma-se, ainda, o projeto "Autor na escola", que promove a aquisição e a leitura de obras de um escritor, que comparece à instituição para discutir com os estudantes aspectos relacionados à literatura.

Nesse ambiente, em que a proliferação de leitores parece ser consequência evidente, a professora titular de Língua Portuguesa dos primeiros anos do Ensino Médio, relata grande dificuldade em estimular a leitura entre os alunos. Segundo ela, os jovens adquirem livros recomendados pela escola, mas não os leem, sob diversas justificativas. Esse desinteresse é estendido a outras atividades culturais, como a assistência a peças teatrais, cujo dia de apresentação não é divulgado para evitar uma ausência "em massa" dos alunos.

$\mathrm{Na}$ base dessas manifestações, pode-se identificar o descrédito social que recai sobre a escola pública, que deixou de ser vista como centro de referência cultural e cujas referências literárias, portanto, não atendem às demandas de identificação dos jovens. Nesse contexto, buscou-se realizar atividades prévias à leitura de Harry Potter, com vistas a registrar expectativas e opiniões dos alunos, bem como a envolvê-los no universo ficcional de J. K. Rowling, com o recebimento de uma carta de aceite à Escola de Magia de Hogwarts, acompanhada de um enigma, a ser desvendado com a leitura da obra. 
Ainda que a indicação da obra a ser lida tenha contado com grande percentual de aprovação pelos alunos - $77 \%$ na turma 1 e 95\% na turma 2 - e que sua leitura tenha sido prevista como tema de recesso de inverno do ano letivo de 2017, na data agendada para o início das atividades - 31 de julho -, nenhum estudante havia lido integralmente o livro e menos de $20 \%$ de cada turma havia iniciado a leitura. Esse fato demandou mudanças na ordem das atividades do roteiro e a mobilização de estratégias, como a cobrança da leitura de seis a oito capítulos como tema de casa semanal.

Inicialmente, o procedimento engendrou mobilização efetiva dos alunos, mas não pôde garantir o término da leitura pela maioria dos estudantes, que identificou o acúmulo de provas e de trabalhos de final de trimestre e atividades laborais como principais empecilhos. Assim, segundo questionário final, na turma 1, 5\% dos alunos leram integralmente a obra, 32\% leram parcialmente, 36\% pretendem terminar a leitura e $27 \%$ não leram a obra. Já na turma $2,12,5 \%$ dos alunos leram integralmente a obra, 25\% leram parcialmente, $50 \%$ pretendem terminar a leitura e $12,5 \%$ não leram a obra.

Um dos fatores que pode ter contribuído para a interrupção de leitura por parte dos alunos foi a dificuldade 
em compreender a linguagem da obra, considerada complexa, com muitas palavras desconhecidas, como revelaram estudantes na produção textual, ao final do roteiro. No entanto, o ponto fulcral provavelmente está na valoração e na abordagem pedagógica das atividades de leitura no contexto escolar. Foram frequentes queixas dos jovens por não conseguirem responder às atividades do roteiro somente com a assistência ao filme homônimo à narrativa de Rowling. Também houve grande espanto com a inclusão de atividades a respeito de Harry Potter e a pedra filosofal na prova trimestral, considerada a avaliação principal e "mais séria", que, portanto, deve abranger os principais conteúdos da disciplina.

Na perspectiva dos estudantes, a leitura é uma atividade periférica, uma espécie de instrumento para acessar os "conteúdos" do ensino de línguas. Não foi aleatório, portanto, o maior envolvimento dos alunos com as atividades do roteiro com enfoque linguístico, como a análise dos tipos de discurso inseridos na obra e os significados do emprego de recursos gráficos no texto. Em contrapartida, questões que demandavam abstração e estabelecimento de relações semânticas entre ações da narrativa, características de personagens e notações espaço-temporais não granjearam 
o interesse da maioria dos estudantes, pois requisitavam grande esforço interpretativo. Para a resolução dessas atividades, fez-se necessária a intervenção das pesquisadoras, primeiramente para compreensão plena do enunciado das questões e, posteriormente, para o estabelecimento de analogias que facilitassem a reflexão sobre a narrativa.

Outro momento importante do roteiro, a produção textual, revelou mais lacunas na formação leitora dos estudantes. Havendo a possibilidade de escolha entre a redação de um texto argumentativo e de uma narrativa ficcional, houve ampla preferência pela primeira opção. O processo de escrita manteve as instabilidades já constatadas durante a realização do roteiro, já que a exigência da reescrita - segundo os estudantes, nunca requisitada até então motivou muito a maioria dos alunos, provocou a resistência de outros e susteve a indiferença de um pequeno grupo.

Vale assinalar, ainda, a influência do coletivo nas reações individuais e na recepção da leitura. Na turma 2, por exemplo, em que houve uma expectativa mais positiva em relação à obra, sustentada por alunos que constituem lideranças, os índices de leitura foram melhores que na turma 1, em que os líderes demonstravam desagrado à seleção da narrativa de Rowling. Curiosamente, porém, as redações com melhor fundamentação argumentativa foram observadas na turma 
1, justamente porque a qualidade da obra e suas fragilidades foram mais amplamente discutidas e confrontadas com outras narrativas lidas pelos alunos.

De modo geral, houve significativas evoluções em textos cujos autores se propuseram a aprimorar a escrita. A fim de exemplificação, na IMAGEM 1, são reproduzidas a primeira e a última versão da carta argumentativa de uma aluna, que ampliou seu texto com a exposição da temática da narrativa e com a inserção do argumento de identificação do leitor jovem com a obra, concatenando de maneira mais eficaz as ideias expostas.

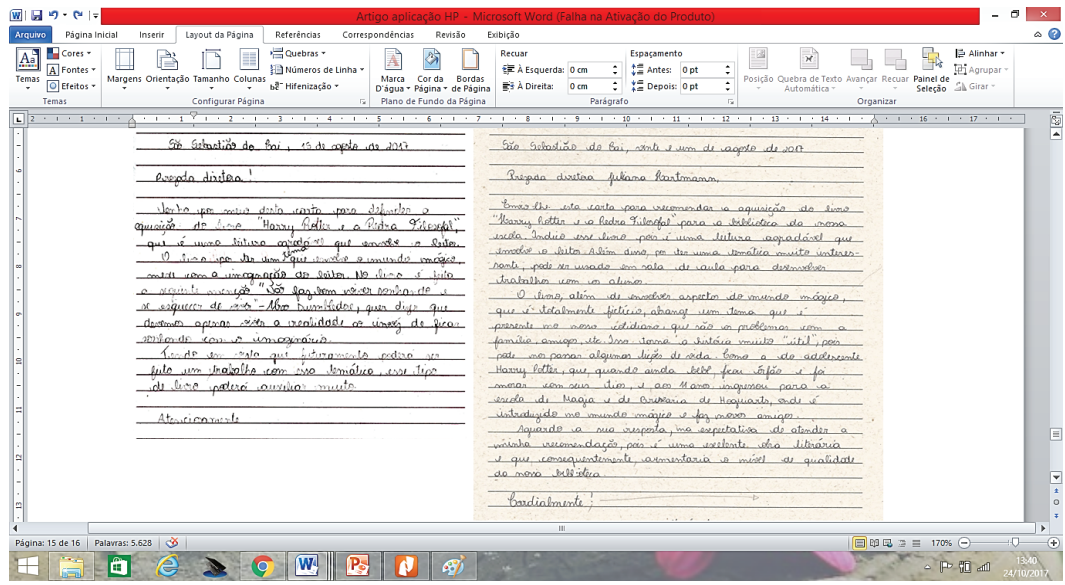

IMAGEM 1: acervo constante da tese de doutorado de AUTOR.

Nas produções da aluna, é manifesta a tentativa de justificar a aquisição da obra por meio da atribuição de uma "utilidade" a ela. A concepção de que a leitura deve servir a 
um propósito prático permeou, com recorrência, a exposição de alunos, sobretudo os contrários à leitura de Harry Potter. Para eles, a ficção "não acrescenta em nada" porque não capacita para a vida em sociedade, oferecendo modelos de conduta e respondendo a dilemas típicos da adolescência ${ }^{4}$. Paradoxalmente, quando questionados sobre os tipos de leitura adequados à fase em que se encontram, esses jovens citaram obras igualmente ficcionais, como 0 rapaz que não era de Liverpool, de Caio Ritter; O senhor dos anéis, de J. R. R. Tolkien; Diário de um banana, de Jeff Kinney, romances de John Green e de Nicholas Sparks. A diferença fundamental que parece sustentar este último grupo como as ficções desejáveis pelos jovens é, simplesmente, sua exclusão do contexto escolar.

\section{PROBLEMATIZAÇÕES SOBRE O CONCEITO DE LITERATURA E O PRAGMATISMO DO CONTEXTO ESCOLAR}

Em que pesem fatores extrínsecos à tessitura narrativa das obras literárias, como o investimento midiático em torno de best sellers recém-lançados, os conceitos e finalidades atribuídos à formação literária em contexto escolar possuem

\footnotetext{
4 Há, por parte dos autores, o reconhecimento de que o primeiro livro da saga Harry Potter apresenta o protagonista em uma fase anterior à da adolescência em que se encontram os alunos de Ensino Médio, o que pode embaraçar parcialmente a identificação com a narrativa. Todavia, tratando-se de um trabalho coletivo, fez-se necessária a opção pelo início da obra de Rowling, com vistas a garantir a inteligibilidade das ações aos leitores que não haviam tido contato com a história escrita.
} 
um peso extra. Quando os alunos insistem no pragmatismo do conteúdo de um livro, estão reproduzindo uma concepção de educação voltada ao preparo para o trabalho e para as funções práticas da vida. Numa perspectiva racionalista de ser humano, que não dá conta do desenvolvimento de habilidades emocionais, estéticas e sociais em sua plenitude, o conhecimento indireto e não pragmático das manifestações artísticas é rejeitado como "inútil".

Nessa conjuntura, a indicação de leitura de obras literárias costuma se dar predominantemente na disciplina de Literatura e com a justificativa de elas serem veículos de informação sobre épocas passadas, de fornecerem cultura e erudição ou de constituírem conteúdo cobrado em provas de vestibular. Opera-se, dessa maneira, uma redução radical do conceito de literatura e de ficção.

Cientes das implicações dessa concepção arraigada nas tradicionais práticas pedagógicas, as pesquisadoras esforçaram-se em esclarecer, desde o primeiro dia de trabalho com o roteiro, que o objetivo fundamental não era o de levar os alunos a gostarem de Harry Potter ou de considerarem a obra como um clássico admirável. O propósito que norteou as ações foi o de inserir os estudantes em um debate acerca da literatura, tendo por base a leitura da obra selecionada, 
de forma a aprimorar seu senso crítico e propiciar a inserção social que o acesso às diferentes manifestações culturais afiança.

A exposição clara do objetivo, aliada à abordagem diferenciada do texto literário, a qual recebeu o reconhecimento por sua qualidade de planejamento em produções textuais de alunos e que deu abertura à participação dos adolescentes na construção do sentido textual, estimulou o compartilhamento espontâneo de experiências de leitura dos alunos e mobilizou interessantes reflexões sobre o local da literatura no contexto escolar e na vida dos alunos. Uma estudante que, com surpresa, revelou que nunca havia imaginado que Harry Potter pudesse ser literatura, trouxe, na última aula, um caderno com anotações sobre as obras que tem lido. A partir de citações de A culpa é das estrelas, de John Green, e de $O$ pequeno príncipe, de Antoine de Saint-Exupéry, reconstitui sua luta contra a obesidade e o bullying decorrente dela, tendo encontrado respaldo nas leituras que fez.

Outros dois estudantes da turma 1, que são lideranças e que criticaram veementemente a leitura de Harry Potter, acabaram por escrever textos argumentativos favoráveis à obra. Quando inquiridos sobre o porquê de fazê-lo, 
justificaram que as fragilidades da narrativa não anulam suas qualidades e que, após lerem a obra, continuam não gostando dela, mas são capazes de compreender o porquê de outros jovens serem atraídos pela saga. Assim, nas suas redações, são destacadas a "linguagem acessível, sem se tornar banal"; a descrição dos espaços, que, associados à realidade, provocam adesão do leitor; a identificação com dilemas da adolescência e o emprego de formas variadas de discurso.

$\mathrm{Na}$ variedade de argumentos das cartas redigidas por alunos, bem como no emprego concreto do discurso indireto livre e de outros recursos narrativos e linguísticos nas narrativas elaboradas por estudantes que optaram pela produção ficcional, desdobram-se aprendizagens efetivadas na realização do roteiro de leitura. Evidentemente, muitos alunos não têm consciência do conhecimento implicado nesse processo de leitura, mesmo porque os jovens participaram com diferentes graus de engajamento, de expectativas e de bagagem cultural.

Nesse contexto, constatar resultados expressivos, sobretudo em relação às lideranças das turmas, ainda que possa parecer uma postura elitista, aponta para um posicionamento realista frente à educação. Não é possível, 
com uma única obra e um único roteiro, inseridos em um trabalho isolado, acolher a diversidade de anseios de um grupo de jovens e romper com a resistência arraigada na cultura de desvalorização da escola pública. É preciso ter em mente que toda modificação de abordagem pedagógica implica estranhamento, pois envolve alterações conceituais e retira os sujeitos de zona de conforto.

Em contrapartida, verificar, já na primeira experiência de alunos jovens com roteiros de leitura, resultados expressivos, como a capacidade de compreender que a avaliação da qualidade estética de uma obra não se confunde com preferências particulares, atesta a relevância de uma proposta metodológica que situa o texto - e não dados extratextuais - no centro das questões e que confere ao aluno-leitor o protagonismo da interpretação. Reiterase, dessa maneira, a eficiência dos roteiros de leitura, se inscritos em um projeto contínuo de leitura e que transite pelas variadas esferas da produção literária.

Enfim, acolher a necessidade que os jovens revelam de compartilhar suas experiências de leitura e senti-las valorizadas é um primeiro passo para a formação leitora e deve integrar o planejamento do professor. Todavia, ressalte-se que nenhuma caminhada eficiente e construtiva 
se faz sem que se conjuguem vários passos àquele inicial. Portanto, é preciso garantir ao aluno o direito que ele tem de acessar diferentes culturas e, sobretudo, de conhecer mais profundamente a sua própria. A escola de Hogwarts pode ser a primeira estação da viagem pelo universo ficcional, cujas paradas, contudo, multiplicam-se no cortiço de João Romão; na casa de Matacavalos de Bentinho; nos pampas de Blau Nunes; no árido sertão de Fabiano e sua família; na cidade livre dos candangos; nas nebulosas ruelas de $K$.; nas redes dos irmãos Omar e Yaqub; no purgatório visitado por João Grilo, até, um dia, quem sabe, navegar na barca de Gil Vicente.

\section{REFERÊNCIAS}

BRASIL (2006). Orientações curriculares para o Ensino Médio: Linguagens e suas tecnologias. In http://portal.mec.gov.br/seb/arquivos/pdf/book_ volume_01_internet.pdf. Acesso em 19.Abr.2017.

CADEMARTORI, Ligia (2012). O professor e a Literatura: para pequenos, médios e grandes. Belo Horizonte: Autêntica Editora.

CANDIDO, Antonio (2002). Textos de intervenção. Seleção, apresentações e notas de Vinícius Dantas. 34.ed. São Paulo: Duas Cidades.

(2004). O direito à literatura. In: Vários escritos. Rio de Janeiro: Duas Cidades/Ouro sobre Azul.

COLOMER, Teresa (2007). Andar entre livros: a leitura literária na escola. Laura Sandroni (Trad.). São Paulo: Global.

ECO, Umberto (1986). Lector in fabula. Attílio Cancian (Trad.). São Paulo, Perspectiva. 
JAUSS, Hans Robert (1978). Pour une esthétique de la récepcion. Paris: Gallimard.

JOUVE, Vincent (2002). A leitura. Brigitte Hervot (Trad.). São Paulo: Editora UNESP.

LAJOLO, Marisa (2002). Do mundo da leitura para a leitura do mundo. 6.ed. São Paulo: Ática.

MEC. Portal do Ministério da Educação. In http://portal.mec.gov.br/ component/tags/tag/33531. Acesso em 25.Out.2017.

ORLANDI, Eni Pulcinelli (1988). O inteligível, o interpretável e o compreensível. In: ZILBERMAN, Regina; SILVA, Ezequiel Theodoro da. Leitura: perspectivas interdisciplinares (Orgs.). São Paulo: Editora Ática, p.58-77.

RAMOS, Graça (2015). Os cortes chegamà literatura. In http://blogs.oglobo. globo.com/graca-ramos/post/os-cortes-chegam-literatura-568230.html. Acesso em 25.Out.2017.

SARAIVA, Juracy Assmann (2001). Literatura e Alfabetização: do plano do choro ao plano da ação. Porto Alegre: Artes Médicas.

; MÜGGE, Ernani et al (2006). Literatura na escola - propostas para o ensino fundamental. Porto Alegre: Artmed.

et al (2011). Palavras, brinquedos e brincadeiras: cultura oral na escola. Porto Alegre: Artmed.

; MÜGGE, Ernani; CUNHA, Simone M. dos Santos (Orgs.) (2015).

Cultura e Identidade: reflexão, leitura e escrita. Porto Alegre: Mosca, v.1.

Juracy Assmann Saraiva é Doutora em Teoria Literária pela PUC/RS e PósDoutora em Teoria Literária pela UNICAMP. Professora e pesquisadora da Universidade Feevale e bolsista em produtividade do CNPq. Integra o grupo de pesquisa "Linguagens e Manifestações Culturais" (Feevale). E-mail: juracy@feevale.br.

Tatiane Kaspari é Doutoranda e Mestra em Processos e Manifestações Culturais, pela Universidade Feevale. Bolsista PROSUC (CAPES), integra 
o grupo de pesquisa "Texto literário: espaço de reflexão crítica e de formação de sujeito". E-mail: tatianekaspari@yahoo.com.br.

Márcia Rohr Welter é Graduanda em Letras (UNISINOS) e bolsista de iniciação científica PROBIC (FAPERGS). Integra o grupo de pesquisa "Texto literário: espaço de reflexão crítica e de formação de sujeito". E-mail: marcia_r_welter@hotmail.com. 